\title{
Perbandingan Dos Sinaran antara Prosedur Urografi Intravena (IvU) dan Tomografi Berkomputer Helikal Tanpa Kontras (UHCT) Urografi
}

(Radiation Dose Comparison between Intravenous Urography (IVU) and Unenhanced Helical Computed Tomography (UHCT) Urography)

AKmal Sabarudin*, Kanaga Kumari Chelliah \& Hamzaini ABdul Hamid

\begin{abstract}
ABSTRAK
Urografi intravena (IVU) dan tomografi berkomputer helikal tanpa kontras (UHCT) urografi adalah dua prosedur utama yang akan dijalankan semasa kajian radiologi bagi pengesanan urolitiasis (batu karang) pada sistem genitourinari. Dedahan terhadap sinaran radiasi merupakan faktor kebimbangan utama dalam kedua-dua prosedur. Oleh itu, satu kajian perbandingan dos sinaran telah dijalankan antara prosedur IVU dan UHCT urografi di samping menentukan faktor dedahan optimum bagi kedua-dua prosedur tersebut. Kajian ini telah dijalankan ke atas fantom antropomorfi seluruh tubuh mengikut protokol sebenar bagi prosedur UHCT urografi dan penghasilan radiografi bersiri beserta dengan pemberian media berkontras bagi prosedur IVU. Sebanyak tiga parameter dedahan voltan tiub digunakan iaitu 75, 80 dan 85 kVp bagi prosedur IVU dan 100, 120 dan 140 kVp bagi prosedur UHCT urografi. Hasil dos sinaran bagi prosedur IVU yang diperoleh adalah 1.40, 2.10 dan $2.79 \mathrm{mSv}$ bagi 75, 80 dan $85 \mathrm{kVp}$. Manakala bagi prosedur UHCT urografi, sebanyak 0.76, 1.32 dan $1.82 \mathrm{mSv}$ dos sinaran direkodkan bagi 100, 120 dan $140 \mathrm{kVp}$. Hasil kualiti imej optimum adalah menggunakan dedahan sebanyak 85 kVp bagi prosedur IVU dan 120 kVp bagi prosedur UHCT urografi. Kesimpulannya, walaupun tidak terdapat perbezaan signifikan, dos sinaran yang terhasil daripada prosedur IVU adalah tekal lebih tinggi daripada prosedur UHCT urografi.
\end{abstract}

Kata kunci: Dos sinaran; kualiti imej; tomografi berkomputer helikal tanpa kontras urografi; urografi intravena

\section{ABSTRACT}

Intravenous urography (IVU) and unenhanced helical computed tomography (UHCT) urography are the two main procedures performed in the radiological investigation for urolithiasis (urinary tract stone). However, exposure to ionizing radiation is the main concern in both procedures. Therefore, a dose comparison study was conducted between IVU and UHCT urography procedures to determine the optimum exposure parameters in this study. An anthropomorphic whole body phantom was used following the exact procedure of UHCT urography and series of imaging for IVU with an administration of contrast media. Three different exposure parameters were used for IVU with 75, 80 and $85 \mathrm{kVp}$ while 100, 120 and $140 \mathrm{kVp}$ for UHCT urography, respectively. As a result, the radiation doses for IVU were $1.40,2.10$ and $2.79 \mathrm{mSv}$ corresponding to 75, 80 and $85 \mathrm{kVp}$, respectively. On the other hand, the radiation doses for UHCT urography were 0.76, 1.32 and $1.82 \mathrm{mSv}$ for 100, 120 and $140 \mathrm{kVp}$, respectively. However the optimum image was obtained at $85 \mathrm{kVp}$ for IVU and $120 \mathrm{kVp}$ for UHCT urography. In conclusion, the doses obtained from IVU were consistently higher than UHCT urography but not significantly different.

Keywords: Image quality; intravenous urography; radiation dose; unenhanced helical computed tomography urography

\section{PENDAHULUAN}

Prosedur urografi intravena (IVU) merupakan prosedur berkontras yang masih diguna pakai sehingga kini dalam pengesanan urolitiasis atau kalkuli trek urinari kerana mempunyai keberkesanan diagnostik yang tinggi (Kim \& Cho 2003). Namun begitu, prosedur ini bukanlah menjadi pengukuran piawai dalam penilaian trek urinari kerana sensitiviti yang rendah dalam pengesanan lesi kecil serta kontraindikasi pesakit kepada media berkontras. Satu prosedur menggunakan imbasan tomografi berkomputer (CT) yang dinamakan sebagai tomografi berkomputer helikal tanpa kontras (UHCT) urografi telah diperkenalkan untuk penilaian terhadap lesi kecil dapat dilakukan dengan lebih berkesan. Penggunaan hirisan yang lebih nipis secara berterusan di samping tidak menggunakan media berkontras menjadi faktor utama mengapa prosedur UHCT urografi lebih menjadi pilihan berbanding IVU (Kim \& Cho 2003).

Namun begitu, kedua-dua prosedur IVU dan UHCT urografi melibatkan penggunaan sinaran mengion dengan pendedahan terhadap sinaran akan memberi kesan stokastik terhadap organ radiosensitif di dalam kawasan rantau abdomen dan pelvis seperti testis, ovari, ginjal dan kelenjar adrenal kerana ia boleh memberikan kesan 
buruk terhadap pembentukan sel dan genetik seperti mutasi sel atau kromosom pada sebarang dos sinaran ambang (Hall 1999).

Sehubungan dengan itu, beberapa kajian perbandingan dos sinaran antara prosedur UHCT urografi dan IVU telah dilakukan bagi menilai taburan dos sinaran yang diterima oleh pesakit sepanjang prosedur tersebut (Nawfel et al. 2004; Parsons et al. 2003; Pfister et al. 2003). Kajian mendapati bahawa dos yang diterima oleh fantom seluruh tubuh pada prosedur UHCT urografi bertabur secara seragam dan lebih tinggi sebanyak 2 kali ganda (11.20 mSv) berbanding prosedur IVU (5.55 $\mathrm{mSv}$ ) (Nawfel et al. 2004; Pfister et al. 2003). Menurut kajian lain, modifikasi pada parameter dedahan CT seperti menggunakan pic yang tinggi dan voltan tiub yang rendah dapat mengurangkan dos sinaran semasa prosedur UHCT urografi sehingga $2.8 \mathrm{mSv}$ (Meagher et al. 2001; Rossee et al. 2000). Peningkatan pic daripada 1.0 ke 2.0 juga mampu mengurangkan dos sinaran sebanyak 50\% (Moller 2000). Manakala prosedur IVU yang melibatkan penghasilan imej radiografi secara bersiri antara 5 hingga 6 dedahan juga dikhuatiri menghasilkan dos sinaran yang tinggi kepada pesakit (Meagher et al. 2001).

Oleh sebab itu, satu uji kaji mengenai perbandingan dos sinaran antara prosedur IVU dan prosedur UHCT urografi dijalankan bagi mengukur jumlah dos sinaran yang diterima oleh pesakit. Selain itu, kajian ini juga bertujuan untuk menentukan parameter dedahan yang optimum bagi kedua-dua prosedur tersebut.

\section{BAHAN DAN KAEDAH}

Kajian yang dijalankan merupakan sebuah kajian prospektif berbentuk eksperimen dos sinaran ke atas fantom seluruh tubuh (Pixy, USA) dengan menggunakan dua modaliti yang berbeza iaitu pengimbas CT (Somatom Sensation 16, Siemens, Jerman) bagi prosedur UHCT urografi dan mesin sinar-x konvensional (ML02F, GE Medical Systems, USA) bagi prosedur IVU. Media berkontras tidak ionik (Iopamiro 300, Bracco, Italy) juga digunakan bagi memberikan kontras imej pada trek urinari dalam prosedur IVU.

\section{PROSEDUR UROGRAFI INTRAVENA}

Kajian dijalankan mengikut protokol sebenar prosedur IVU sebanyak 5 siri dedahan radiografi meliputi 4 radiografi rantau kidney-ureter-bladder (KUB) dan satu radiografi rantau ginjal (kidney view). Ringkasan prosedur IVU ditunjukkan dalam carta alir pada Rajah 1.

Dalam kajian ini, sebanyak tiga faktor dedahan berlainan voltan tiub digunakan sebagai parameter dedahan iaitu 75, 80 dan $85 \mathrm{kVp}$ dengan nilai half-value layer (HVL) sebanyak $2.5 \mathrm{~mm}$ Al. Manakala arus tiub yang digunakan dikawal secara automatik. Oleh kerana hanya satu fantom yang digunakan bagi setiap parameter dedahan, ketebalan dan ketumpatan tisu yang adalah tetap arus tiub yang digunakan sepanjang pemeriksaan adalah malar bagi menghasilkan imej dengan kontras dan densiti

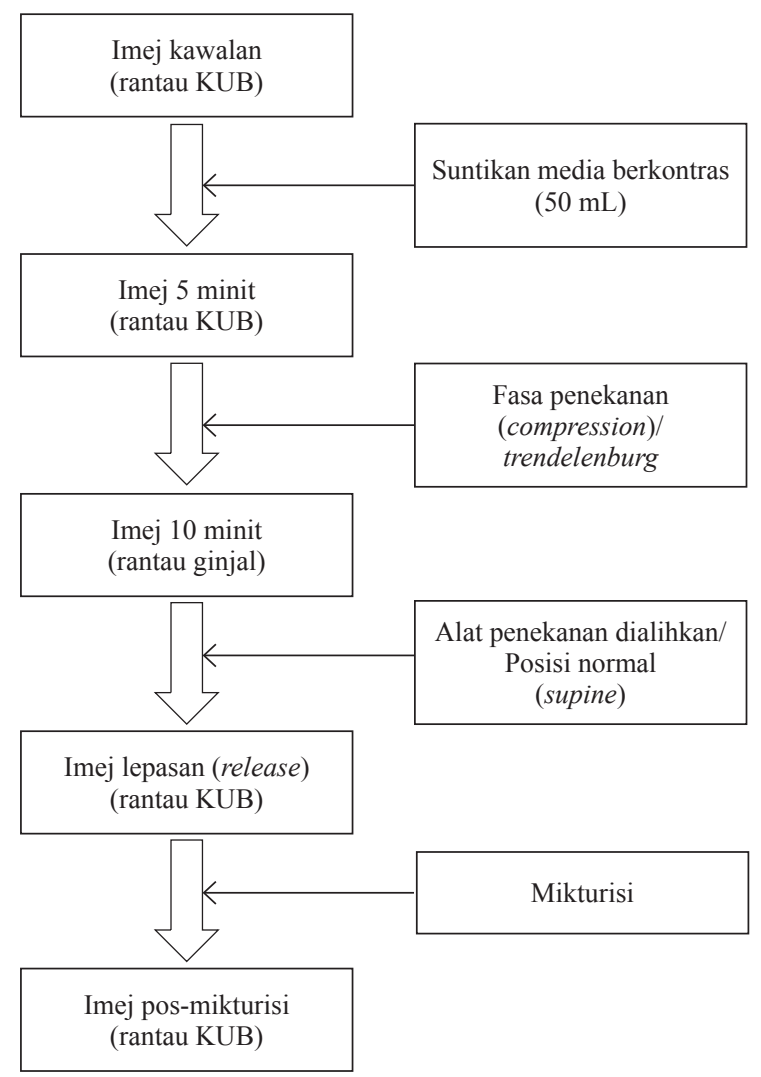

RAJAH 1. Carta alir prosedur IVU yang melibatkan 5 siri pengimejan bermula dengan penghasilan imej kawalan sehingga penghasilan imej pos-mikturisi 
yang optimum (32 mAs bagi kesemua faktor dedahan). Setiap siri dedahan diulang sebanyak tiga kali.

\section{PROSEDUR TOMOGRAFI BERKOMPUTER HELIKAL TANPA KONTRAS UROGRAFI}

Prosedur UHCT urografi dijalankan dengan menggunakan kolimasi pengesan $16 \times 1.5 \mathrm{~mm}$, ketebalan hirisan sebanyak $5.0 \mathrm{~mm}$, medan imbasan berjulat daripada 270 hingga $330 \mathrm{~mm}$, pergerakan meja pemeriksaan per-putaran gantri sebanyak $10.8 \mathrm{~mm}$; pic sebanyak 1.0 , nilai $\mathrm{HVL}$ sebanyak $5 \mathrm{~mm} \mathrm{Al}$, dengan tiga faktor dedahan berlainan $(100,120$ dan $140 \mathrm{kVp})$ dengan arus tiub yang dikawal secara automatik (300-500 mAs). Walaupun arus tiub dikawal secara automatik, nilai arus tiub maksimum yang ditetapkan adalah sebanyak $350 \mathrm{~mA}$ bagi ketiga-tiga faktor dedahan dengan nilai efektif milliampere-second (mAs) akan ditentukan berdasarkan tempoh masa imbasan dan juga ketebalan objek yang diimbas. Oleh kerana hanya satu fantom yang digunakan, maka nilai mAs yang diberi adalah malar pada setiap protokol yang digunakan. Selain itu, nilai pic yang digunakan adalah dalam julat 1.0 hingga 3.0 dengan ketebalan hirisan sebanyak $5.0 \mathrm{~mm}$ (Meagher et al. 2001).

Sebelum imbasan dilakukan, satu imej topografi perlu dihasilkan bertujuan untuk perancangan plana hirisan sebenar bagi imbasan prosedur UHCT urografi. Dua teknik bagi mengurangkan dos sinaran pada pesakit semasa imbasan topografi dilakukan iaitu penggunaan parameter dedahan minimum ( $80 \mathrm{kVp}$ dan $50 \mathrm{mAs}$ ) dan putaran tiub sinar-x juga sebanyak $180^{\circ}$ (Sperry \& Knowles 2005).

\section{PENGUKURAN DOS SINARAN}

Dos sinaran yang diukur dalam kajian ini adalah entrance skin dose (ESD) dan pengukuran dos sinaran ini dilakukan dengan menggunakan cip TLD-100. Cip-cip TLD diletakkan di atas permukaan kulit fantom pada kawasan organ radiosensitif semasa dedahan dilakukan bagi menentukan radiasi pada titik tertinggi daripada taburan dos keseluruhan yang merangkumi radiasi daripada bim primer dan sekunder. Dalam kajian ini, gonad merupakan organ radiosensitif yang dipilih untuk menentu ukur jumlah dos sinaran yang diterima. Dos sinaran dibaca dan direkod dalam milligray (mGy) selepas melalui satu siri pemprosesan bacaan dos yang merangkumi proses sepuh lindap dan kalibrasi.

Proses sepuh lindap dan bacaan dos dilakukan menggunakan mesin Harshaw-5500 (Thermo Electron Corp., USA) sementara kalibrasi dilakukan menggunakan mesin sinar-x $(\mathrm{HVL}=2.5 \mathrm{~mm} \mathrm{Al})$, mesin tomografi berkomputer $(\mathrm{HVL}=5.0 \mathrm{~mm} \mathrm{Al})$ dan beberapa alatan lain seperti survei meter sinaran digital (model 660) dan kebuk pengionan (model 660-3) unit pembaca dos (model 660-1). Kalibrasi TLD dilakukan bagi mendapatkan bentuk graf bagi penukaran dos sinaran daripada unit nanoculomb (nC) kepada milligray (mGy) dengan pendedahan sinaran yang dikenal pasti nilainya. TLD hanya diproses selepas 24 jam didedahkan kepada sinaran radiasi. TLD yang digunakan dalam kajian ini berbentuk mikro-segiempat sama dan dibungkus dengan plastik bernombor.

Jumlah cip TLD yang digunakan adalah sebanyak 72 keping cip iaitu sebanyak 36 keping cip bagi prosedur IVU dan 36 keping cip bagi prosedur UHCT urografi. Setiap parameter dedahan bagi prosedur IVU memerlukan sebanyak 3 keping cip TLD yang dilekatkan pada kawasan gonad dan 1 keping cip sebagai kawalan. Setiap parameter dedahan pula akan diulang sebanyak 3 kali dengan menggunakan cip TLD berlainan bagi mendapatkan bacaan purata. Bacaan purata ini akan direkodkan bagi mengurangkan ketakpastian pengukuran. Teknik pengukuran dos (ESD) yang sama juga digunakan bagi prosedur UHCT urografi di mana teknik lokalisasi cip TLD adalah pada kawasan gonad.

\section{PENILAIAN KUALITI IME.}

Penilaian kualiti imej bagi prosedur IVU dan UHCT urografi dilakukan oleh dua orang pakar radiologi yang mempunyai pengalaman lebih dari 10 tahun dalam penilaian imej radiografi. Kedua-dua orang pakar radiologi tersebut tidak dimaklumkan mengenai faktor dedahan dan protokol pengimejan. Setiap set imej dinilai secara subjektif menggunakan skor 4-point. Perincian mengenai skala penilaian kualiti imej ditunjukkan dalam Jadual 1.

\section{ANALISIS STATISTIK}

Data yang diperoleh dianalisis menggunakan perisian SPSS versi 19.0 (SPSS Inc, Chicago, USA). Secara

JADUAL 1. Perincian skor bagi penilaian kualiti imej

\begin{tabular}{|c|c|c|}
\hline Skor & Tafsiran skala & Perincian \\
\hline 1 & Sangat baik & $\begin{array}{l}\text { Semua struktur dapat ditunjukkan dengan jelas tanpa kehadiran sebarang artifak. Penilaian terhadap } \\
\text { imej dapat dilakukan dengan baik dan berkesan kerana imej terhasil mempunyai nilai diagnostik } \\
\text { yang tinggi }\end{array}$ \\
\hline 2 & Baik & $\begin{array}{l}\text { Kehadiran hingar yang mengganggu kejelasan struktur sempadan salur darah beserta kehadiran } \\
\text { artifak yang minimum. Imej masih mempunyai nilai diagnostik dan penilaian imej dapat dilakukan } \\
\text { dengan baik }\end{array}$ \\
\hline 3 & Memuaskan & $\begin{array}{l}\text { Kekaburan pada struktur sempadan salur darah. Paparan struktur anatomi agak terhad akibat hehadiran } \\
\text { hingar yang tinggi. Imej yang mempunyai nilai diagnostik yang terhad dan penilaian imej masih } \\
\text { boleh dilakukan }\end{array}$ \\
\hline 4 & Tidak memuaskan & $\begin{array}{l}\text { Sempadan salur darah dan tisu sekeliling tidak jelas kelihatan. Kehadiran hingar yang tinggi } \\
\text { mengganggu penglihatan struktur anatomi serta penilaian terhadap imej tidak dapat dilakukan }\end{array}$ \\
\hline
\end{tabular}


statistiknya, perbezaan yang signifikan ditentukan oleh pekali statistik, $\mathrm{p}$ sekiranya nilai $p<0.05$. Ujian-t dua hujung, korelasi Pearson dan ujian statistik kappa digunakan dalam kajian ini.

\section{KEPUTUSAN}

\section{PERBANDINGAN DOS SINARAN DALAM PROSEDUR IVU DAN UHCT UROGRAFI}

Dalam prosedur IVU, dos sinaran yang diperoleh bagi setiap parameter dedahan adalah berbeza secara signifikan. Dos sinaran efektif yang diperoleh adalah sebanyak $1.40 \pm 0.01$, $2.10 \pm 0.02$ dan $2.79 \pm 0.03 \mathrm{mSv}$ bagi dedahan 75,80 dan $85 \mathrm{kVp}$. Perincian dos untuk siri radiografi bagi prosedur IVU ditunjukkan dalam Jadual 2. Kajian ini juga menunjukkan bahawa terdapat hubungan korelasi linear yang signifikan antara dos sinaran dengan parameter dedahan $(\mathrm{kVp})$ yang digunakan dalam prosedur IVU (Rajah 2(a)).

Prosedur UHCT urografi juga menunjukkan bahawa dos sinaran radiasi berbeza secara signifikan bagi setiap

JADUAL 2. Perincian dos efektif (ED) bagi setiap imej dedahan dalam prosedur IVU

\begin{tabular}{lccc}
\hline \multicolumn{1}{c}{$\begin{array}{c}\text { Bahagian imej } \\
\text { dedahan }\end{array}$} & \multicolumn{3}{c}{ Faktor dedahan $(\mathrm{mSv})$} \\
\cline { 2 - 4 } & $75 \mathrm{kVp}$ & $80 \mathrm{kVp}$ & $85 \mathrm{kVp}$ \\
\hline Imej kawalan & $0.31 \pm 0.00$ & $0.53 \pm 0.00$ & $0.66 \pm 0.00$ \\
Imej 5 minit & $0.30 \pm 0.00$ & $0.48 \pm 0.00$ & $0.63 \pm 0.00$ \\
Imej 10 minit & $0.01 \pm 0.00$ & $0.01 \pm 0.00$ & $0.02 \pm 0.00$ \\
Imej lepasan & $0.36 \pm 0.00$ & $0.51 \pm 0.01$ & $0.67 \pm 0.01$ \\
Imej pos-mikturisi & $0.39 \pm 0.00$ & $0.57 \pm 0.01$ & $0.82 \pm 0.01$ \\
$\begin{array}{l}\text { Dos kawalan } \\
\text { Dos kumulatif }\end{array}$ & $0.04 \pm 0.00$ & $0.11 \pm 0.00$ & $0.09 \pm 0.00$ \\
prosedur & $1.40 \pm 0.01$ & $2.10 \pm 0.02$ & $2.79 \pm 0.03$ \\
\hline
\end{tabular}

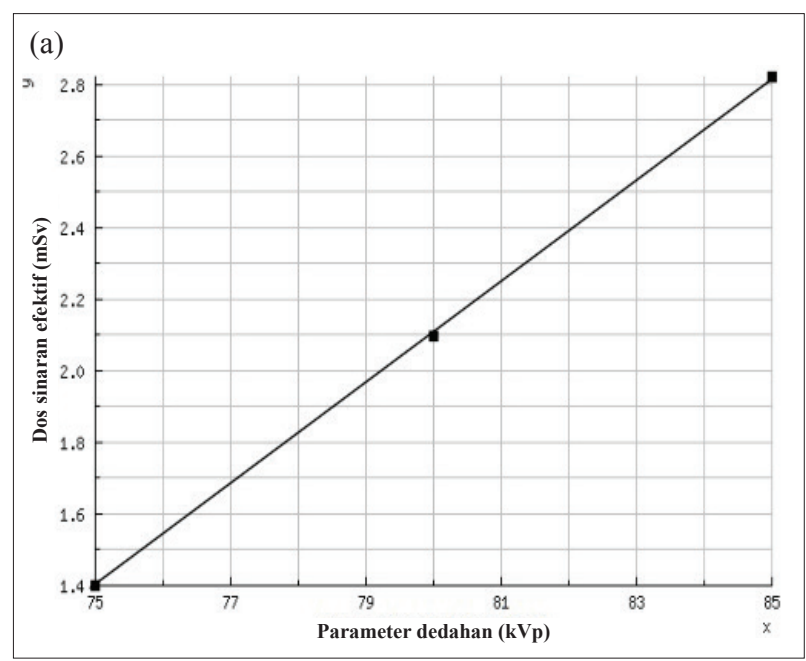

parameter dedahan yang digunakan dengan jumlah ESD yang diperoleh adalah sebanyak $0.76 \pm 0.06,1.32 \pm 0.04$ dan $1.82 \pm 0.08 \mathrm{mSv}$ bagi dedahan 100, 120 dan 140 $\mathrm{kVp}$ dengan dengan pic sebanyak 1.0. Kajian ini juga menunjukkan bahawa terdapat hubungan korelasi linear yang signifikan antara dos sinaran dengan parameter dedahan $(\mathrm{kVp})$ yang digunakan dalam prosedur UHCT urografi (Rajah 2(b)).

\section{PENILAIAN KUALITI IMEJ BAGI PROSEDUR IVU DAN UHCT UROGRAFI}

Penilaian imej secara subjektif telah dilakukan oleh dua orang pakar radiologi mendapati bahawa imej optimum yang terhasil bagi prosedur IVU adalah menggunakan faktor dedahan sebanyak 85 kVp (Rajah 3(a-e)). Persetujuan ini telah dicapai oleh kedua-dua penilai dengan skor kappa yang sangat baik iaitu sebanyak 0.68. Manakala dedahan optimum bagi prosedur UHCT urografi adalah sebanyak $120 \mathrm{kVp}$ (Rajah 4) dan telah dipersetujui oleh kedua-dua penilai dengan skor kappa yang sangat baik pada 0.74 .

\section{PERBINCANGAN}

Kajian ini mengilhamkan dua keputusan penting yang boleh dijadikan panduan dan rujukan untuk aplikasi klinikal. Pertama, terdapat perbezaan signifikan dalam jumlah dos sinaran yang akan diterima pesakit sekiranya faktor dedahan diubah $(\mathrm{kVp})$ samada bagi prosedur IVU ataupun UHCT urografi. Kedua, faktor dedahan yang dipilih jelas menunjukkan kesan secara langsung terhadap pembentukan imej kerana semakin tinggi voltan tiub yang dipilih, semakin tinggi penembusan sinaran terhadap objek sekaligus mengurangkan sinaran terserak yang memberikan hingar dan keterukan kualiti sesuatu imej.

Dalam kajian ini, didapati bahawa dos sinaran efektif yang diperoleh semasa prosedur UHCT adalah jauh lebih rendah (0.76-1.82 $\mathrm{mSv})$ berbanding prosedur IVU (1.40-

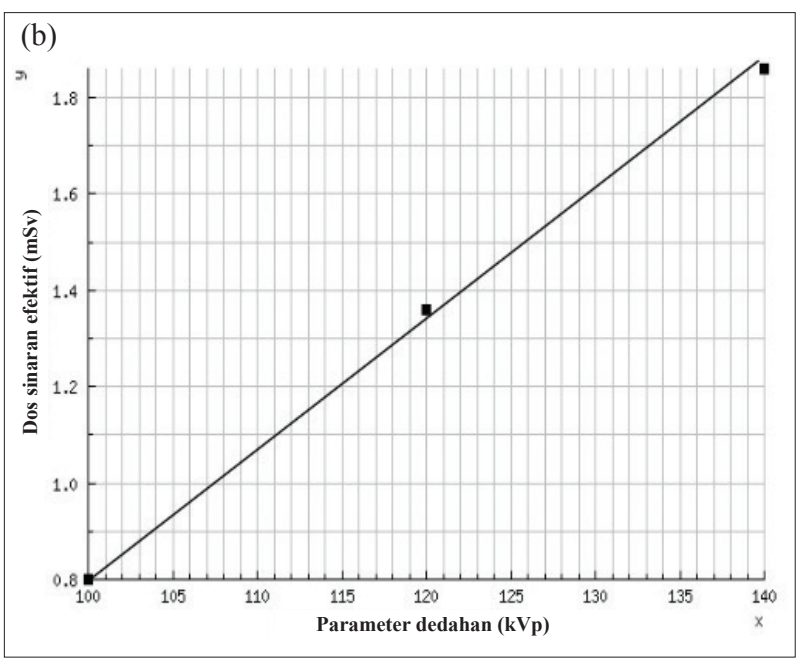

RAJAH 2. Graf korelasi antara parameter dedahan $(\mathrm{kVp})$ dan dos sinaran efektif (mSv), (a) Terdapat hubungan linear yang kuat $\left(\mathrm{R}^{2}=0.97\right)$ antara dos sinaran dan parameter dedahan bagi prosedur IVU seperti yang ditunjukkan dalam taburan dos pada graf. (b) Graf yang mewakili prosedur UHCT urografi juga menunjukkan terdapat kekuatan hubungan yang positif $\left(\mathrm{R}^{2}=0.94\right)$ dari hasil korelasi antara dos sinaran dan parameter dedahan 

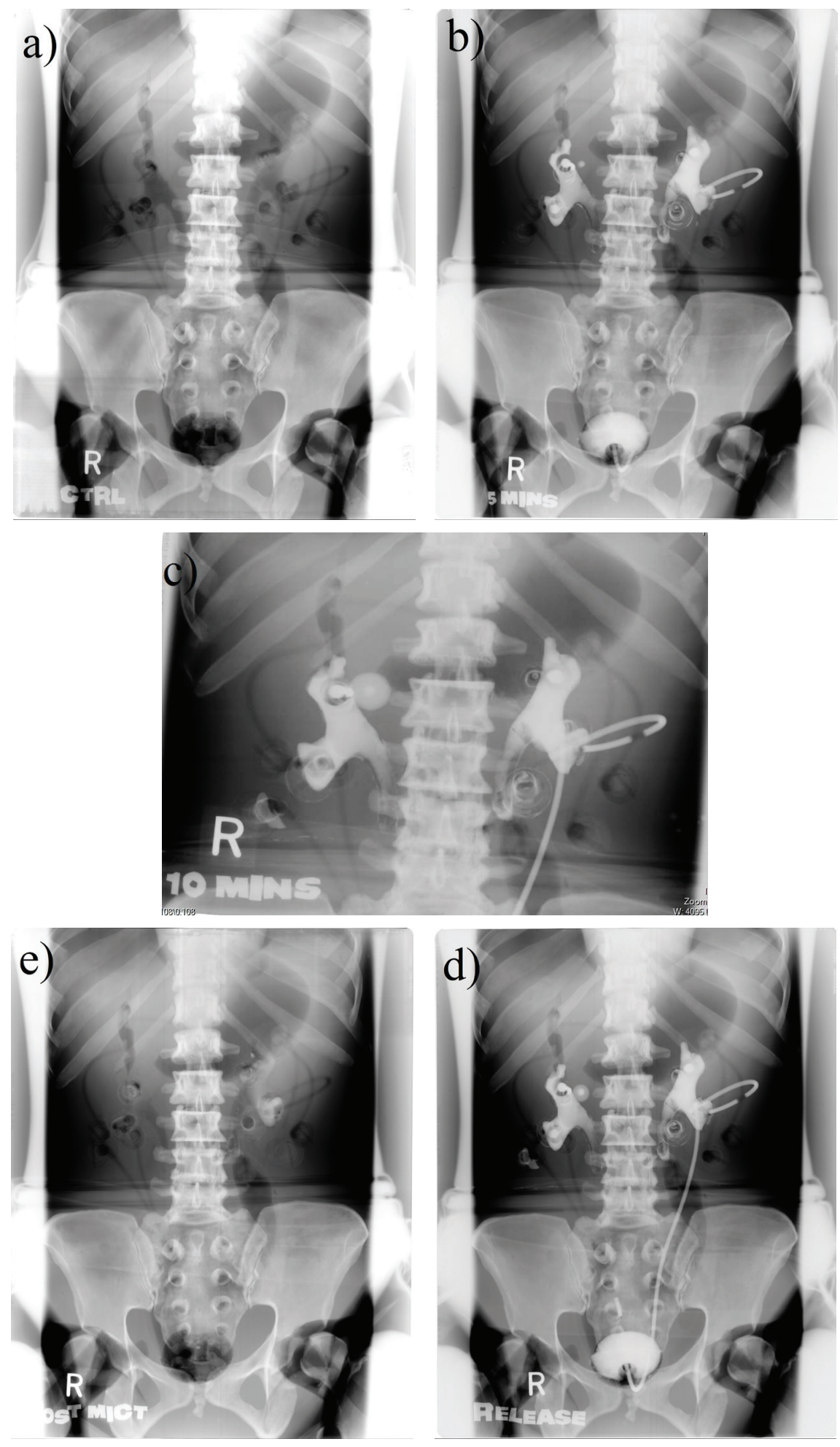

RAJAH 3. Imej bersiri bagi prosedur IVU merangkumi (a) imej kawalan, (b) imej 5 minit selepas pemberian media berkontras, (c) imej 10 minit selepas melalui posisi trendelenburg, (d) imej lepasan (release) yang bertujuan bagi meningkatkan aliran kontras pada distal ureter. (e) Imej pos-mikturisi dihasilkan setelah media berkontras dibersihkan daripada trek urinari fantom

$2.79 \mathrm{mSv})$ dan ia bertentangan dengan kajian-kajian terdahulu $(\mathrm{UHCT}=11.20 \mathrm{mSv}$; IVU $=5.55 \mathrm{mSv})(\mathrm{Nawfel}$ et al. 2004; Pfister et al. 2003). Ini adalah disebabkan beberapa faktor seperti pengenalan perisian dos rendah pada sistem tomografi berkomputer (Silverman et al. 2009) dan pengubahsuaian teknik topografi semasa prosedur UHCT (Sperry \& Knowles 2005).
Andaian bahawa penggunaan kolimasi bim kecil semasa penghasilan imej rantau ginjal semasa prosedur IVU dipercayai dapat mengurangkan dos sinaran pada pesakit adalah meleset sama sekali. Ini kerana kolimasi yang kecil pada rantau ginjal hanya dilakukan sekali sahaja daripada keseluruhan siri pengimejan IVU. Ini sekaligus menjadi faktor alasan mengapa dos efektif 


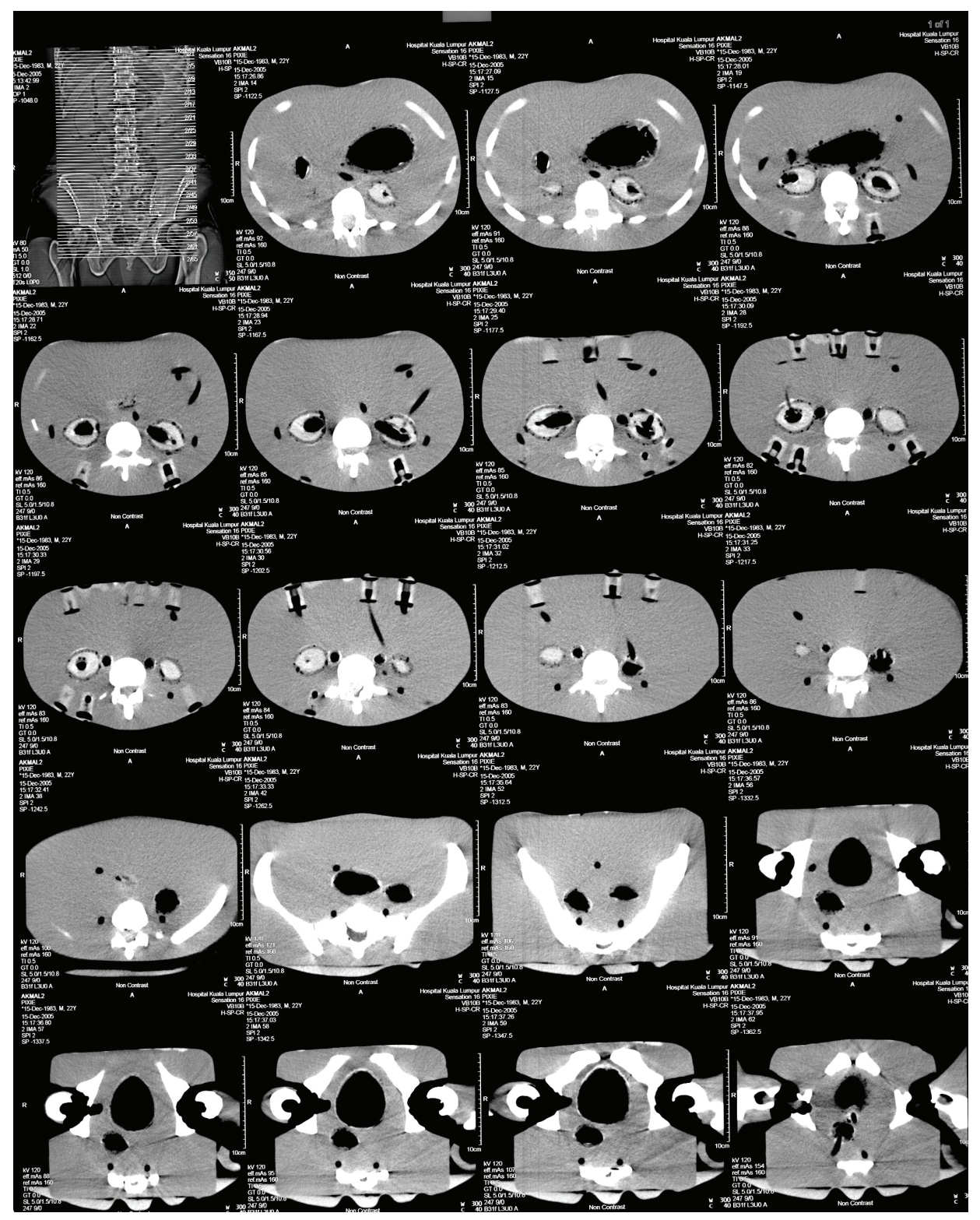

RAJAH 4. Imej hirisan lintang (axial) pada kaviti abdomen dan pelvis bagi prosedur UHCT urografi

semasa prosedur IVU lebih tinggi berbanding dos sinaran setara dalam prosedur UHCT urografi (Yakoumakis et al. 2001). Kajian lain menyokong bahawa dos sinaran yang diukur diluar kolimasi bim adalah sangat rendah secara signifikan sekaligus menjadikan penggunaan kolimasi bim adalah faktor utama dalam kaedah perlindungan sinaran terutama semasa pemeriksaan radiografi pediatrik (Armpilia et al. 2002).

Selain itu, teknologi termaju dalam pembangunan unit CT juga membantu memberikan dos sinaran yang rendah kepada pesakit dengan beberapa teknik tertentu seperti pengubahsuaian bim semasa penghasilan imej topografi. Teknik pengubahsuaian dalam menghasilkan imej topografi menjadi faktor utama pengurangan dos sinaran radiasi dalam prosedur imbasan tomografi berkomputer urografi. Dalam kajian ini, modifikasi yang telah dilakukan adalah dengan menggunakan tiub sinar-x pada posisi $180^{\circ}$ menjadikannya pada kedudukan posterior pesakit. Ini dapat mengurangkan sinaran radiasi pada pesakit kerana sinaran yang terhasil akan menghentam meja pemeriksaan CT terdahulu sebelum menembusi badan pesakit. Fenomena ini akan menyebabkan tenaga sinar-x yang rendah akan diserap oleh meja pemeriksaan dan secara tidak langsung, ia akan mengurangkan dos radiasi pada kawasan gonad, tiroid, payudara dan kawasan berdekatan tanpa menjejaskan kualiti imej (Sperry \& Knowles 2005).

Penggunaan perisian pengurangan dos sinaran atau combined applications to reduce exposure (CARE) pada kawalan mAs automatik menjadikan mesin tomografi berkomputer hirisan berganda 16 hirisan berupaya menghasilkan dos sinaran yang jauh lebih rendah berbanding mesin CT biasa yang tidak mempunyai perisian tersebut. Ini sekaligus dapat memberikan andaian terhadap pengurangan dos sinaran dalam kajian ini (Silverman et al. 2009). 
Perbezaan penggunaan voltan tiub dalam penghasilan imej IVU mahupun UHCT urografi telah menunjukkan bahawa terdapat satu pilihan utama imej terbaik bagi setiap prosedur. Pemilihan imej ini ditentukan daripada sokongan faktor densiti yang memuaskan, hingar latar belakang dan penghasilan kontras imej yang sangat bagus (Pallwein-Prettner et al. 2011). Namun begitu, tiada skala tetap klasifikasi bagi penilaian imej yang dilakukan secara subjektif kerana ia bergantung sepenuhnya kepada mata pemerhati semata-mata.

Terdapat beberapa masalah yang timbul sepanjang kajian dijalankan. Pertama, penggunaan parameter dedahan yang sedikit. Penggunaan parameter yang sedikit sekaligus menjejaskan kenormalan taburan data. Namun begitu, selepas melakukan proses saringan terhadap pemilihan faktor dedahan berdasarkan imej radiografi, imej yang terhasil daripada faktor dedahan yang tidak bersesuaian (underexposed dan overexposed) telah disingkirkan dan meninggalkan hanya 3 faktor dedahan yang bersesuaian dengan ketebalan fantom antropomorfi. Kedua, penilaian kualiti imej yang terhasil daripada prosedur IVU tidak begitu memuaskan akibat penggunaan fantom yang tidak mempunyai struktur anatomi yang lengkap sekaligus menimbulkan kesukaran dalam penilaian imej oleh pakar radiologi. Penilaian kualiti imej terjejas akibat ketiadaan beberapa organ badan yang penting dalam trek urinari untuk dinilai seperti tisu parenkima ginjal, 1/3 ureter tengah dan $1 / 3$ ureter inferior.

Kesimpulannya, dengan teknologi termaju yang diadaptasi pada sistem tomografi berkomputer (Silverman et al. 2009; Sperry \& Knowles 2005), UHCT urografi berjaya menghasilkan dos sinaran jauh lebih rendah berbanding prosedur IVU walaupun tidak terdapat perbezaan yang signifikan secara statistik. Selain itu, daripada penilaian imej dalam kajian ini jelas menunjukkan bahawa prosedur IVU dengan faktor dedahan sebanyak $85 \mathrm{kVp}$ dan prosedur UHCT urografi dengan faktor dedahan sebanyak $120 \mathrm{kVp}$ menjadi pilihan utama dalam penerimaan imej secara diagnostik.

\section{RUJUKAN}

Armpilia, C.I., Fife, A.J. \& Croasdale, P.L. 2002. Radiation dose quantities and risk in neonates in a special care baby unit. British Journal of Radiology 75: 590-595.

Hall, E.J. 1999. Radiobiology for the Radiologist. Ed ke-5. Philadelphia: Lippincott Williams \& Wilkins.

Kim, J.K. \& Cho, K.S. 2003. CT urography and virtual endoscopy: Promising imaging modalities for urinary tract evaluation. British Journal of Radiology 76: 199-209.

Meagher, T., Sukumar, V.P., Collingwood, J., Crawley, T., Schofield, D., Henson, J., Lakin, K. \& Connolly, J.G. 2001. Low dose computed tomography in suspected accute renal colic. Clinical Radiology Journal 56(11): 873-876.
Moller, T.B. 2000. Normal Findings in Radiology. Ed. Ke-2. Italy: CIC Edizioni Internazionali.

Nawfel, R.D., Judy, P.F., Schleipman, A.R. \& Silverman, S.G., 2004. Patient radiation dose at CT urography and conventional urography. Radiology 232: 126-132.

Pallwein-Prettner, L., Flory, D., Rotter, C.R., Pogner, K., Syre, G., Fellner, C., Frauscher, F., Aigner, F., Krause, F.S. \& Fellner, F. 2011. Assessment and characterization of common renal masses with CT and MRI. Insights Imaging 2: 543-556.

Parsons, J.K., Lancini, V., Shetye, K., Regan, F., Potter, S.R. \& Jarret, T.W. 2003. Urinary stone size: Comparison of abdominal plain radiography and non-contrast CT measurement. Journal of EndoUrology 17: 725-728.

Pfister, S.A., Deckart, A., Laschke, S., Dellas, S., Otto, U., Buitrago, C., Roth, J., Wiesner, W. \& Gasser, T.C. 2003. Unenhanced helical computed tomography vs intravenous urography in patients with acute flank pain: Accuracy and economic impact in a randomized prospective trial. European Radiology 13(11): 2513-2510.

Rossee, C.J., Zagoria, R. \& Dixon, R. 2000. Is there a learning curved in diagnostic urolithiasis with noncontrast helical computed tomography? Canada Associates Radiology Journal 51: 177-181.

Silverman, S.G., Levendecker, J.R. \& Amis, E.S. 2009. What is the current role of CT urography and MR urography in the evaluation of the urinary tract? Radiology 250: 309-323.

Sperry, K.J. \& Knowles, P. 2005. Changes in technique can reduce radiation dose in CT examination. American Journal of Roentgenology 185: 509-515.

Yakoumakis, E., Tsalafoutas, I.A., Nikolaou, D., Nazos, I., Koulentianos, E. \& Proukakis, C.H. 2001. Differences in effective dose estimation from dose-area product and entrance surface dose measurements in intravenous urography. British Journal of Radiology 74: 727-734.

Akmal Sabarudi* \& Kanaga Kumari Chelliah Program Pengimejan Diagnostik \& Radioterapi Universiti Kebangsaan Malaysia

43600 UKM Bangi, Selangor Darul Ehsan Malaysia

Hamzaini Abdul Hamid

Pusat Perubatan Universiti Kebangsaan Malaysia

Jalan Yaakob Latiff, Bandar Tun Razak

56000 Cheras, Kuala Lumpur, Wilayah Persekutuan Malaysia

*Pengarang untuk surat-menyurat; email: akmal.sabarudin@ fsk.ukm.my

Diserahkan: 24 April 2013

Diterima: 9 November 2017 
